www.mdpi.com/journal/marinedrugs

Article

\title{
Investigation of Marine-Derived Fungal Diversity and Their Exploitable Biological Activities
}

\author{
Joo-Hyun Hong, Seokyoon Jang, Young Mok Heo, Mihee Min, Hwanhwi Lee, Young Min Lee, \\ Hanbyul Lee and Jae-Jin Kim *
}

Division of Environmental Science \& Ecological Engineering, College of Life Sciences \& Biotechnology, Korea University, 145 Anam-ro, Seongbuk-gu, Seoul 136-713, Korea; E-Mails: dress8@korea.ac.kr (J.-H.H.); skel@korea.ac.kr (S.J.); hym011@korea.ac.kr (Y.M.H.); mihee1220@korea.ac.kr (M.M.); ghksgn127@korea.ac.kr (H.L.); ymlee25@korea.ac.kr (Y.M.L.); hblee95@korea.ac.kr (H.L.)

* Author to whom correspondence should be addressed; E-Mail: jae-jinkim@korea.ac.kr; Tel.: +82-2-3290-3049; Fax: +82-2-953-0737.

Academic Editor: Johannes F. Imhoff

Received: 31 March 2015 / Accepted: 15 June 2015 / Published: 30 June 2015

\begin{abstract}
Marine fungi are potential producers of bioactive compounds that may have pharmacological and medicinal applications. Fungi were cultured from marine brown algae and identified using multiple target genes to confirm phylogenetic placement. These target genes included the internal transcribed spacer (ITS), the nuclear large subunit (LSU), and the $\beta$-tubulin region. Various biological activities of marine-derived fungi were evaluated, including their antifungal, antioxidant and cellulolytic enzyme activities. As a result, a total of 50 fungi was isolated from the brown algae Sargassum sp. Among the 50 isolated fungi, Corollospora angusta was the dominant species in this study. The genus Arthrinium showed a relatively strong antifungal activity to all of the target plant pathogenic fungi. In particular, Arthrinium saccharicola KUC21221 showed high radical scavenging activity and the highest activities in terms of filter paper units $(0.39 \mathrm{U} / \mathrm{mL})$, endoglucanase activity $(0.38 \mathrm{U} / \mathrm{mL})$, and $\beta$-glucosidase activity $(1.04 \mathrm{U} / \mathrm{mL})$.
\end{abstract}

Keywords: antioxidant activity; biological control; cellulolytic enzyme activity; marine fungi; phylogenetic analysis 


\section{Introduction}

The marine environment is extremely complex and contains a broad spectrum of fungal diversity. Although a variety of new marine-derived fungal genera have been identified and evaluated [1], numerous marine fungi are identical to terrestrial fungi, e.g., Aspergillus spp., Cephalosporium spp., Fusarium spp., or Penicillium spp. [2,3]. Marine-derived fungi have been discovered in various locations such as sediment, sponges, microalgae, fish, the deep sea and mangrove wood [4]. However, high-resolution taxonomic identification of marine fungi is still lacking because the majority of studies have only been resolved to the genus level [5-7]. Because species within a genus can differ highly in their biological activities, it is necessary to assess DNA-based information at the finest resolution. Thus, the fungal internal transcribed spacer (ITS) is commonly used to identify fungi $[8,9]$ but is unable to classify some taxa at the species level [10,11]. To remedy this deficiency in accuracy and show high resolution in early diverging lineages, a multi-gene phylogenetic analysis was utilized [10,12]. Numerous marine-derived fungi were investigated through multi-gene phylogeny $[3,13]$.

In addition, immense efforts have been made to investigate marine-derived compounds. Unique and stressful marine habitats have profound effects on fungal biological activity. Many marine-derived fungal biological activities have been detected, including antifungal, antioxidant, cytotoxic, antitumor, or anti-inflammatory activities [14,15]. Cephalosporin $\mathrm{C}$ in Acremonium chrysogenum was the first bioactive compound found from a marine fungus [16]. Since these discoveries, investigations into natural products and the biological activities of marine-derived fungi have been increasing. Several novel marine natural products were isolated and described. The genus Aspergillus from the marine habitat is well known as a producer of new compounds. Three new phenolic bisabolance-type sesquiterpenoids, meroterpenoids, and aspergillides A-C were isolated from marine-derived Aspergillus sp. [17], A. flavipes [18], and A. ostianus [19], respectively. In particular, avrainvillamide was isolated from marine-derived Aspergillus sp. CNC358 and demonstrated chemotherapeutic properties; it has also shown licensed in vivo activity in preclinical models [20]. Recently, components that were isolated from marine-derived fungi were used in the cosmetic industry. The marine-derived fungal carotenoid and kojic acid are used as ingredients in natural pigments and skin-whitening products [21]. These attractive applications encourage the bio-mining of marine environments. Because cellulosic compounds are in high abundance in marine systems, marine fungi are candidates for the production of novel cellulosic compounds. Additionally, marine fungi are great cellulolytic enzyme production candidates, considering the abundance of cellulosic materials in the marine environment $[22,23]$. Previous studies have reported that marine fungi have cellulase activities that are comparable to those of terrestrial wood-decaying fungi $[24,25]$. The goal of this study was to evaluate the diversity of fungi collected from the brown algae, Sargassum sp., using multigene phylogenetic analysis and to investigate the antifungal, antioxidant, and cellulolytic activities in hopes of finding prospective bioresource agents. 


\section{Results and Discussion}

\subsection{Fungal Phylogeny and Identification}

A total of 50 fungal strains were isolated and investigated from the brown algae (Table 1). Two were identified as zygomycetes: Mucor circinelloides. The other 48 were identified as ascomycetes. Among isolated fungi, six strains were not identified at the species or genus level because their best matched references from BLAST search were lower than $95 \%$ of similarities.

In the phylogenetic tree based on ITS (Figure 1), most species were grouped in their own clade. However, five species, i.e., Acremonium sp. 1, Chaetomium sp., Colletotrichum sp., Eutypella sp., and Paradendryphiella sp., were identified at the genera level because they were grouped in their respective species complex. Six species, i.e., Acremonium sp. 2, Arthrinium sp. 1, Arthrinium sp. 2, Pleosporaceae sp. 1, Pleosporaceae sp. 2, and Valsaria sp., were identified at genera or family level due to their best matched sequences from BLAST search had low similarities. They were placed in their own clade without close reference species. Four species, i.e., Aspergillus sp., Sordariomycetes sp. 2, Sordariomytcetes sp. 3, and Xylaliales sp., were not identified at species level, despite their own clades with references, because two of the other analyzed regions, LSU and $\beta$-tubulin, were not supported by the ITS-based identifications.

The phylogenetic relationship of the ITS-based tree was not clear because some nodes had low posterior probabilities. Thus, phylogenetic tree based on combined dataset from ITS, LSU and $\beta$-tubulin sequences was constructed to confirm simultaneous relationship of the isolates (Figure 2). The outline of this tree was similar to the ITS-based tree. Especially, branching pattern of early diverging nodes that classified taxa into class level was agreed with the ITS-based tree. Therefore, the phylogenetic tree based on ITS region could represent their phylogenetic relationships.

The most abundant species was Corollospora angusta (26\%). C. angusta has a broad distribution in marine habitats, such as algae and mangroves [26-28], but it has not been reported in Korea. It has been suggested that this species is highly associated with its substrate, Sargassum sp. In both MEA and PDA media, this species showed a very slow growth rate (less than $1 \mathrm{~mm}$ per day). The most diverse genus was Arthrinium (12\%), which contained four species (Figures 2 and 3). Arthrinium is a commonly isolated genus from not only plants and soil but also marine environments [7,11]. In Korea, two Arthrinium species, A. arundinis and A. phaeospermum, have been reported [29,30] but have not been fully described. A. arundinis is also known as a plant pathogen of barley [31]. In Korea, A. arundinis was isolated from bamboo [30], but marine A. arundinis has not been reported. The first A. saccharicola was isolated from Saccharum officinarum [32]. Although A. saccharicola has been reported from various habitats, such as plants, air [11], and seawater [33], it has not been reported in Korea. 
Table 1. Biological activities of marine fungi isolated from brown algae. ${ }^{a}$ ABTS, 2,2'-azinobis-(3-ethylbenzothiazoline-6-sulfonic acid);

${ }^{\mathrm{b}} \mathrm{DPPH}, 2$ 2-diphenyl-1-picrylhydrazyl; ${ }^{\mathrm{c}}$ FPU, filter paper unit; ${ }^{\mathrm{d}} \mathrm{EG}$, endoglucanase; ${ }^{\mathrm{e}}$ BGL, $\beta$-glucosidase; ${ }^{\mathrm{f}}$ BXL, $\beta$-xylosidase;

${ }^{\mathrm{g}}$ N.D., not detected.

\begin{tabular}{|c|c|c|c|c|c|c|c|c|c|c|}
\hline \multirow[b]{2}{*}{ Fungal Identity } & \multirow[b]{2}{*}{ ID } & \multicolumn{3}{|c|}{ Antifungal Activity $\mathrm{IC}_{50}(\mu \mathrm{g} / \mathrm{mL})$} & \multicolumn{2}{|c|}{ Antioxidant Activity IC $\mathrm{I}_{50}(\mu \mathrm{g} / \mathrm{mL})$} & \multicolumn{4}{|c|}{ Cellulolytic Enzyme Activity (U/mL) } \\
\hline & & $\begin{array}{l}\text { Botrytis } \\
\text { cinerea }\end{array}$ & $\begin{array}{l}\text { Collectotrichum } \\
\text { gloeosporioides }\end{array}$ & $\begin{array}{c}\text { Fusarium } \\
\text { oxysporum }\end{array}$ & $\begin{array}{c}\text { ABTS }{ }^{a} \text { Radical } \\
\text { Scavenging Activity }\end{array}$ & $\begin{array}{c}\text { DPPH }{ }^{\mathrm{b}} \text { Radical } \\
\text { Scavenging Activity }\end{array}$ & FPU $^{c}$ & $\mathbf{E G}^{\mathbf{d}}$ & BGL ${ }^{\mathrm{e}}$ & BXL ${ }^{f}$ \\
\hline \multicolumn{11}{|l|}{ Ascomycota } \\
\hline \multicolumn{11}{|l|}{ Dothideomycetes } \\
\hline Alternaria alternata & KUC21222 & N.D. ${ }^{g}$ & N.D. & $>1000$ & $>1000$ & N.D. & N.D. ${ }^{g}$ & N.D. & $0.07 \pm 0$ & N.D. \\
\hline Epicoccum nigrum & KUC21264 & $>1000$ & $>1000$ & N.D. & N.D. & N.D. & $0.05 \pm 0.09$ & N.D. & $0.05 \pm 0.01$ & $0.02 \pm 0$ \\
\hline Paradendryphiella sp. & KUC21227 & $>1000$ & N.D. & $>1000$ & N.D. & N.D. & $0.15 \pm 0$ & $0.03 \pm 0.06$ & $0.04 \pm 0$ & N.D. \\
\hline Pleosporaceae sp. 1 & KUC21234 & N.D. & $>1000$ & N.D. & N.D. & N.D. & $0.1 \pm 0.09$ & N.D. & $0.03 \pm 0.02$ & N.D. \\
\hline Pleosporaceae sp. 2 & KUC21239 & N.D. & N.D. & $>1000$ & N.D. & N.D. & N.D. & $0.03 \pm 0.06$ & $0.05 \pm 0$ & N.D. \\
\hline \multirow[t]{3}{*}{ Valsaria sp. } & KUC21230 & $>1000$ & N.D. & $>1000$ & $>1000$ & N.D. & $0.05 \pm 0.08$ & $0.04 \pm 0.07$ & $0.01 \pm 0.02$ & N.D. \\
\hline & KUC21231 & N.D. & N.D. & N.D. & N.D. & N.D. & N.D. & N.D. & $0.03 \pm 0.02$ & N.D. \\
\hline & KUC21259 & N.D. & N.D. & 559.0 & $>1000$ & N.D. & N.D. & $0.08 \pm 0.08$ & $0.02 \pm 0.03$ & N.D. \\
\hline \multicolumn{11}{|l|}{ Eurotiomycetes } \\
\hline Aspergillus niger. & KUC21224 & $>1000$ & $>1000$ & 72.5 & 272.2 & $>1000$ & $0.15 \pm 0$ & $0.04 \pm 0.08$ & $0.05 \pm 0$ & $0.02 \pm 0$ \\
\hline Aspergillus sp. & KUC21245 & $>1000$ & N.D. & $>1000$ & $>1000$ & N.D. & N.D. & $0.14 \pm 0.02$ & $0.11 \pm 0.01$ & $0.02 \pm 0$ \\
\hline \multicolumn{11}{|l|}{ Sordariomycetes } \\
\hline \multirow[t]{2}{*}{ Acremonium fuci } & KUC21233 & N.D. & N.D. & $>1000$ & N.D. & N.D. & N.D. & N.D. & N.D. & N.D. \\
\hline & KUC21244 & 523.8 & $>1000$ & N.D. & N.D. & N.D. & N.D. & $0.03 \pm 0.06$ & $0.01 \pm 0.02$ & N.D. \\
\hline Acremonium sp. 1 & KUC21242 & N.D. & $>1000$ & N.D. & N.D. & N.D. & N.D. & N.D. & N.D. & N.D. \\
\hline Acremonium sp. 2 & KUC21262 & N.D. & N.D. & 670.7 & $>1000$ & N.D. & $0.1 \pm 0.09$ & $0.11 \pm 0$ & $0.07 \pm 0.01$ & N.D. \\
\hline \multirow[t]{2}{*}{ Arthrinium arundinis } & KUC21229 & N.D. & N.D. & 193.1 & N.D. & N.D. & $0.1 \pm 0.09$ & $0.17 \pm 0.04$ & $0.05 \pm 0$ & N.D. \\
\hline & KUC21261 & $>1000$ & 590.3 & 225.9 & N.D. & N.D. & $0.1 \pm 0.09$ & $0.18 \pm 0.07$ & $0.04 \pm 0$ & N.D. \\
\hline Arthrinium saccharicola & KUC21221 & 210.5 & N.D. & $>1000$ & 46 & 88.4 & $0.39 \pm 0.13$ & $0.38 \pm 0$ & $1.04 \pm 0.03$ & $0.02 \pm 0$ \\
\hline \multirow[t]{2}{*}{ Arthrinium sp. 1} & KUC21228 & 574.8 & N.D. & 391.8 & N.D. & N.D. & $0.15 \pm 0$ & $0.26 \pm 0.04$ & $0.1 \pm 0.01$ & $0.02 \pm 0$ \\
\hline & KUC21232 & 172.8 & $>1000$ & 139.9 & N.D. & N.D. & $0.15 \pm 0$ & $0.14 \pm 0.02$ & $0.06 \pm 0$ & $0.01 \pm 0.01$ \\
\hline Arthrinium sp. 2 & KUC21220 & 179.9 & $>1000$ & $>1000$ & $>1000$ & $>1000$ & $0.15 \pm 0$ & $0.14 \pm 0.02$ & $0.16 \pm 0.04$ & $0.02 \pm 0$ \\
\hline Chaetomium murorum & KUC21225 & N.D. & N.D. & $>1000$ & N.D. & N.D. & N.D. & N.D. & $0.04 \pm 0$ & N.D. \\
\hline Chaetomium sp. & KUC21238 & N.D. & N.D. & $>1000$ & N.D. & N.D. & N.D. & $0.07 \pm 0.06$ & $0.04 \pm 0$ & N.D. \\
\hline
\end{tabular}


Table 1. Cont.

\begin{tabular}{|c|c|c|c|c|c|c|c|c|c|c|}
\hline Colletotrichum sp. & KUC21226 & $>1000$ & N.D. & $>1000$ & N.D. & N.D. & $0.15 \pm 0$ & $0.13 \pm 0.01$ & $0.04 \pm 0$ & $0.01 \pm 0.01$ \\
\hline \multirow[t]{13}{*}{ Corollospora angusta } & KUC21246 & $>1000$ & N.D. & N.D. & N.D. & N.D. & N.D. & N.D. & N.D. & N.D. \\
\hline & KUC21247 & N.D. & N.D. & $>1000$ & N.D. & N.D. & N.D. & N.D. & N.D. & N.D. \\
\hline & KUC21248 & $>1000$ & N.D. & $>1000$ & N.D. & N.D. & N.D. & N.D. & N.D. & N.D. \\
\hline & KUC21249 & N.D. & N.D. & N.D. & N.D. & N.D. & $0.05 \pm 0.09$ & N.D. & N.D. & N.D. \\
\hline & KUC21250 & N.D. & N.D. & N.D. & N.D. & N.D. & $0.1 \pm 0.09$ & N.D. & N.D. & N.D. \\
\hline & KUC21251 & N.D. & N.D. & N.D. & N.D. & N.D. & $0.1 \pm 0.09$ & N.D. & N.D. & N.D. \\
\hline & KUC21252 & N.D. & N.D. & N.D. & N.D. & N.D. & N.D. & N.D. & N.D. & N.D. \\
\hline & KUC21254 & $>1000$ & N.D. & N.D. & N.D. & N.D. & N.D. & N.D. & N.D. & N.D. \\
\hline & KUC21255 & N.D. & N.D. & N.D. & N.D. & N.D. & N.D. & N.D. & $0.04 \pm 0$ & N.D. \\
\hline & KUC21256 & N.D. & $>1000$ & $>1000$ & N.D. & N.D. & N.D. & N.D. & $0.01 \pm 0.02$ & N.D. \\
\hline & KUC21257 & $>1000$ & $>1000$ & N.D. & N.D. & N.D. & N.D. & N.D. & N.D. & N.D. \\
\hline & KUC21258 & $>1000$ & $>1000$ & N.D. & N.D. & N.D. & N.D. & N.D. & N.D. & N.D. \\
\hline & KUC21260 & $>1000$ & N.D. & $>1000$ & N.D. & N.D. & N.D. & N.D. & N.D. & N.D. \\
\hline \multirow[t]{2}{*}{ Diaporthe arecae } & KUC21217 & N.D. & N.D. & N.D. & N.D. & N.D. & $0.16 \pm 0.01$ & $0.14 \pm 0.03$ & $0.29 \pm 0.08$ & $0.01 \pm 0.01$ \\
\hline & KUC21243 & $>1000$ & N.D. & N.D. & N.D. & N.D. & $0.1 \pm 0.09$ & $0.13 \pm 0.02$ & $0.13 \pm 0.07$ & $0.01 \pm 0.01$ \\
\hline Diatrypella vulgaris & KUC21240 & N.D. & N.D. & 758 & N.D. & N.D. & N.D. & N.D. & N.D. & N.D. \\
\hline \multirow[t]{2}{*}{ Eutypella sp. } & KUC21218 & $>1000$ & N.D. & N.D. & N.D. & N.D. & $0.05 \pm 0.09$ & $0.14 \pm 0.01$ & $0.18 \pm 0.04$ & $0.02 \pm 0$ \\
\hline & KUC21241 & N.D. & $>1000$ & $>1000$ & N.D. & N.D. & N.D. & $0.16 \pm 0.05$ & $0.17 \pm 0.09$ & $0.01 \pm 0.01$ \\
\hline \multirow[t]{2}{*}{ Fusarium oxysporum } & KUC21235 & N.D. & N.D. & $>1000$ & N.D. & N.D. & $0.15 \pm 0$ & N.D. & $0.04 \pm 0$ & $0.01 \pm 0.01$ \\
\hline & KUC21237 & N.D. & N.D. & $>1000$ & N.D. & N.D. & N.D. & N.D. & $0.04 \pm 0$ & N.D. \\
\hline Gibellulopsis nigrescens & KUC21236 & N.D. & N.D. & $>1000$ & N.D. & N.D. & $0.05 \pm 0.09$ & $0.04 \pm 0.06$ & $0.04 \pm 0$ & N.D. \\
\hline Sordariomycetes sp. 1 & KUC21253 & $>1000$ & N.D. & N.D. & N.D. & N.D. & N.D. & N.D. & N.D. & N.D. \\
\hline Sordariomycetes sp. 2 & KUC21223 & $>1000$ & N.D. & N.D. & N.D. & N.D. & N.D. & N.D. & N.D. & N.D. \\
\hline Sordariomycetes sp. 3 & KUC21263 & N.D. & N.D. & $>1000$ & N.D. & N.D. & N.D. & N.D. & $0.04 \pm 0$ & N.D. \\
\hline \multicolumn{11}{|l|}{ Zygomycota } \\
\hline \multicolumn{11}{|l|}{ Mucoromyciotina } \\
\hline \multirow[t]{2}{*}{ Mucor circinelloides } & KUC30061 & $>1000$ & N.D. & $>1000$ & $>1000$ & N.D. & $0.05 \pm 0.09$ & N.D. & $0.13 \pm 0.03$ & $0.01 \pm 0.01$ \\
\hline & KUC30062 & N.D. & N.D. & N.D. & N.D. & N.D. & $0.15 \pm 0$ & $0.04 \pm 0.06$ & $0.05 \pm 0.01$ & N.D. \\
\hline
\end{tabular}




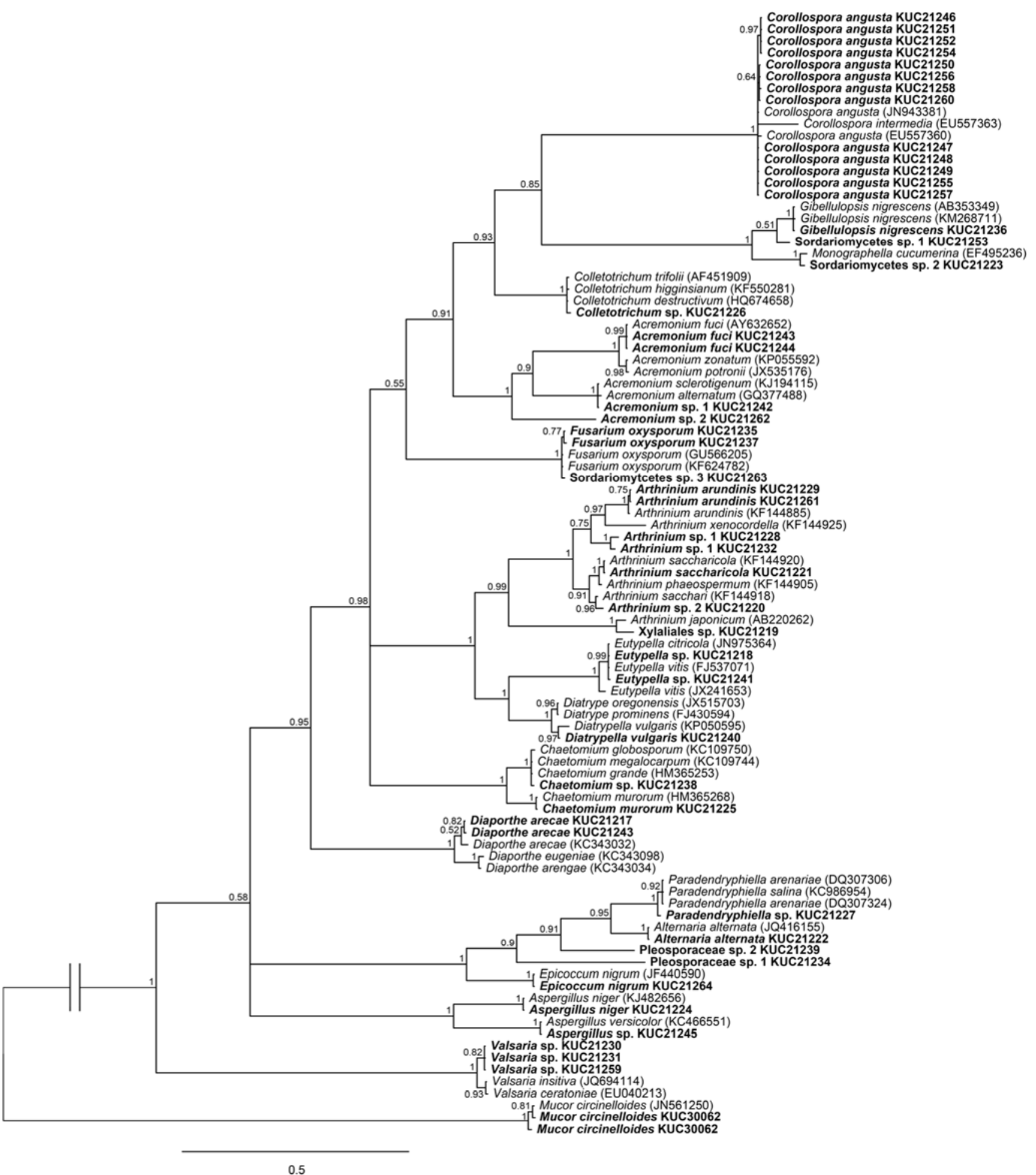

Figure 1. Phylogenetic tree of the fungi isolated from Sargassum sp. (in bold) and their allies based on Internal Transcribed Spacer (ITS). Numbers above branches indicate posterior probabilities. The scale bar indicates nucleotide substitutions per position. 


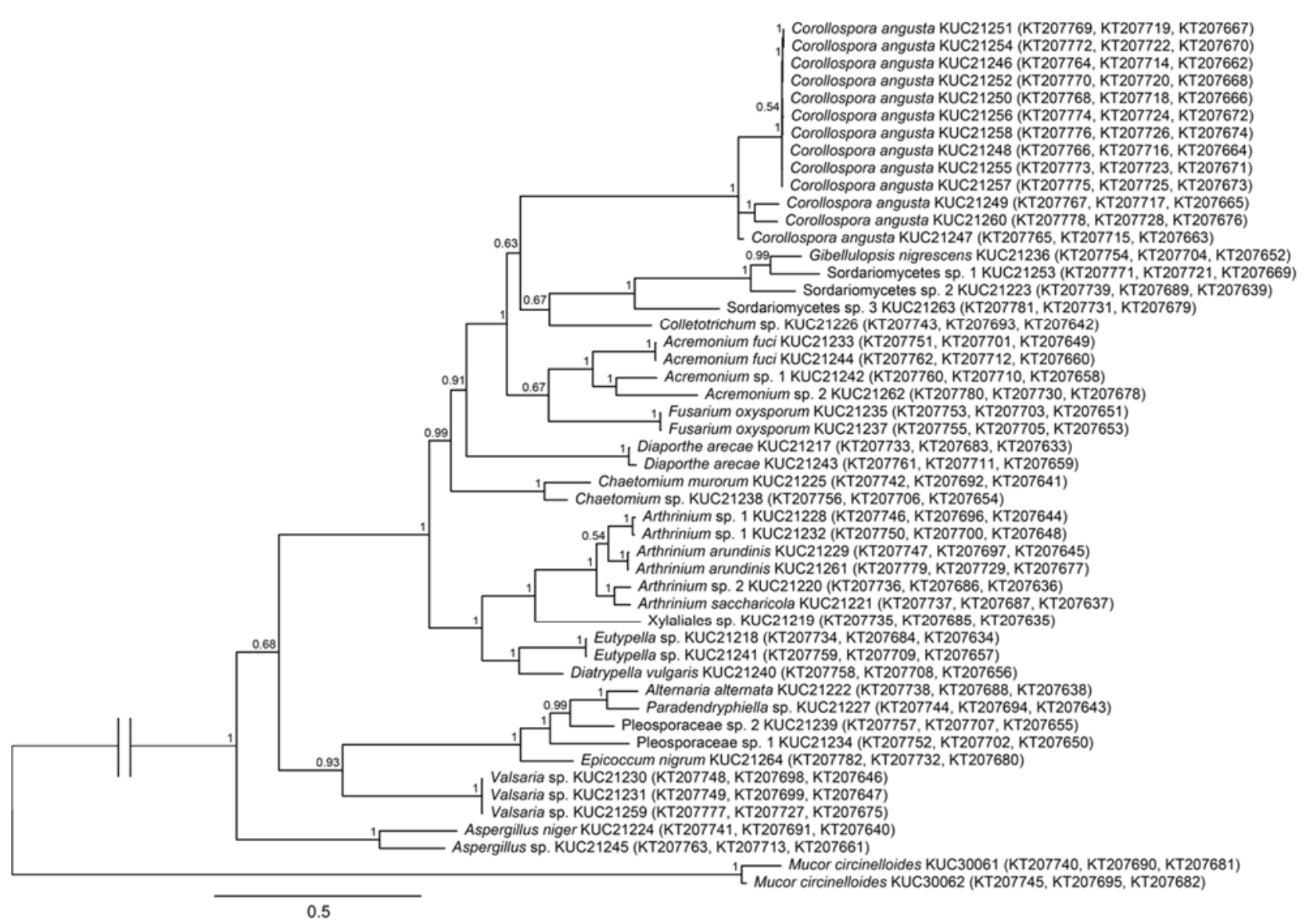

Figure 2. Phylogenetic tree of the fungi isolated from Sargassum sp. and their allies based on combined Internal Transcribed Spacer (ITS), nuclear large subunit rDNA (LSU) and $\beta$-tubulin sequence alignment. Numbers above branches indicate posterior probabilities. The scale bar indicates nucleotide substitutions per position. Genbank accession numbers of ITS, LSU, and $\beta$-tubulin sequences are in parentheses.

In our phylogenetic tree of Arthrinium spp. (Figure 3), each Arthrinium species was classified at the species level with high posterior probability (p.p.). A. arundinis KUC21261 and KUC21229 were placed in a monophyletic clade of $A$. arundinis with a high p.p. (1.0). A. saccharicola KUC21221 was grouped with reference $A$. saccharicola with a high p.p. (1.0). Conversely, Arthrinium sp. 1 KUC21228, KUC21232, and Arthrinium sp. 2 KUC21220 did not join the clade with reference Arthrinium but instead had their own clades. They also demonstrated low similarities with best matched references from BLAST search. We suggest that these unidentified Arthrinium are new species candidates. Further studies with detailed morphological analyses are required to prove the novelty of these species.

Acremonium was the third largest genus in this study (8\%). It is a cosmopolitan genus that is commonly isolated from soil, wood [34,35], and seaweed [7,36]. Aspergillus spp. is a common saprophyte of various substrates [35], and two species were isolated. Some Aspergillus species are halophilic and are commonly observed in marine environments [7,37]. A. niger is common in various environments, including seawater [38,39]. In addition, Fusarium oxysporum, a well-known plant pathogen [40], is a commonly isolated soil fungus worldwide [35], and has been found in marine environments [41]. 


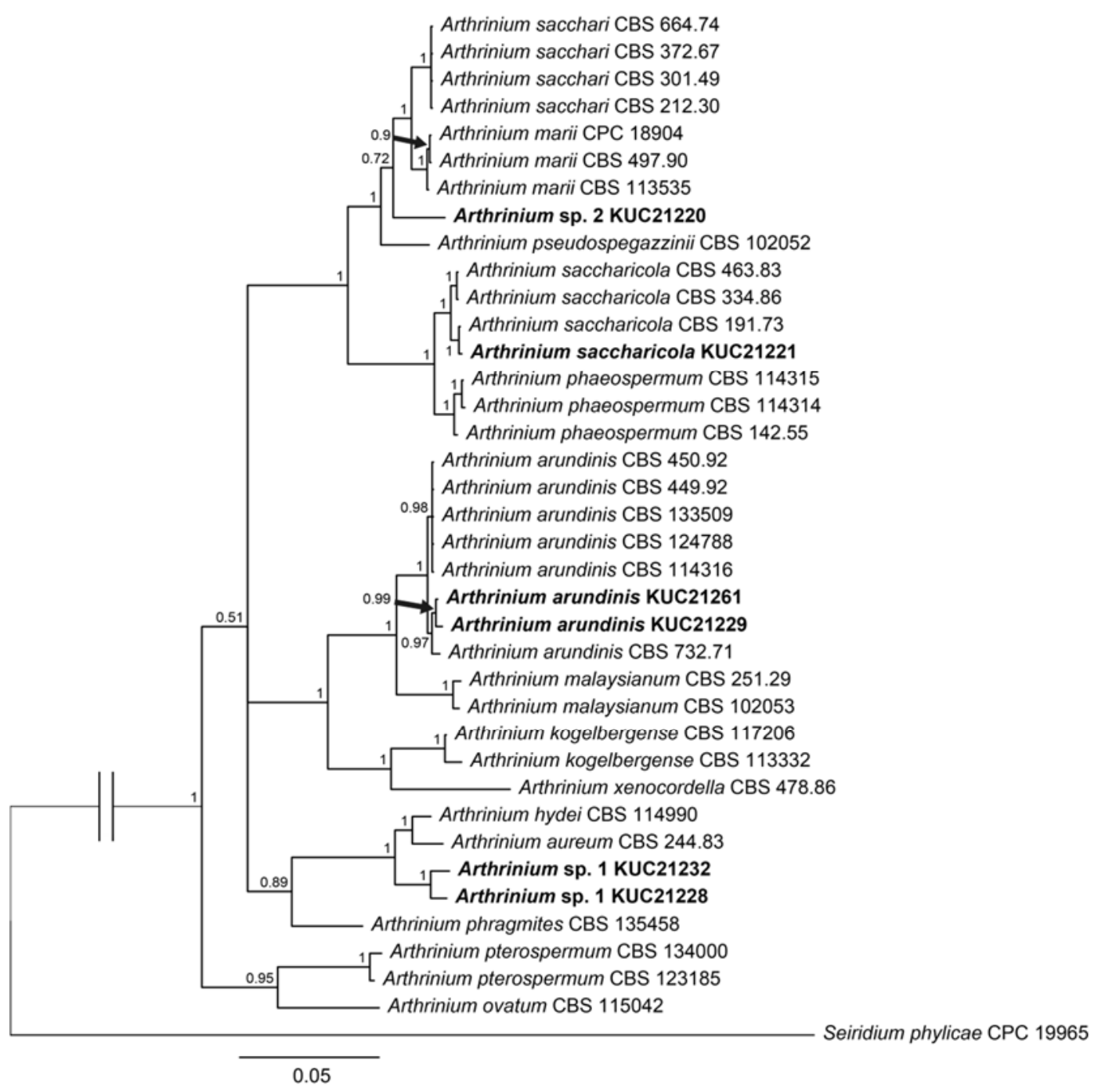

Figure 3. Phylogenetic tree of the Arthrinium spp. isolated from Sargassum sp. (in bold) and their allies based on combined Internal Transcribed Spacer (ITS), nuclear large subunit rDNA (LSU) and $\beta$-tubulin sequence alignment. Numbers above branches indicate posterior probabilities. The scale bar indicates nucleotide substitutions per position.

Mucor circinelloides was the solitary zygomycetous species found in this study. The genus, Mucor has been reported to occur in a variety of seaweed [7]. This saprophytic species is commonly isolated from various environments [35], including seawater [42], and has been utilized in the production of fermented food $[43,44]$ and in biotechnology applications to produce lipids [45] and ethanol [46].

For marine fungi which were not identifiable at the species or genus level, further studies with morphological approaches are required. Certainly, identified fungal diversity data can help further studies on marine fungal diversities.

\subsection{Biological Activities of the Strains}

\subsubsection{Antifungal Activity and Antioxidant Activity}

The antifungal activity of extracts from each strain were examined against three species, Fusarium oxysporum KUC20267, Botrytis cinerea KUC21265, and Collectotrichum gloeosporioides 
KUC21266 (Table 1) in triplicate. At the same dose, the most inhibited phytopathogenic fungus was F. oxysporum. Five strains showed remarkable activities against F. oxysporum: Xylariales sp. KUC21219, Aspergillus niger KUC21224, A. arundinis KUC21229, KUC21261, and Arthninium sp. 1 KUC21232. And B. cinerea, a pathogen of the grape berry and apples, was inhibited by four strains: A. saccharicola KUC21221, Arthrinium sp. 1 KUC21228, Arthrinium sp. KUC21232 and Arthrinium sp. 2 KUC21220. In contrast, C. gloeosporioides was weakly inhibited by marine-derived fungal extracts in this study. Plant pathogenic fungi are the main infection sources of damage during pre- or post-harvest in the agricultural industry.

There are several studies on the biological control of marine-derived compounds against phytopathogenic fungi [14]. Aqueous and ethanolic extracts from marine algae were shown to inhibit B. cinerea and Phytophthora cinnamon [47].

In this study, the genus Arthrinium showed potential antifungal activity to target fungi. To date, over 20 compounds have been isolated and studied from the genus Arthrinium. In particular, the origins of some compounds were marine habitats. Four new compounds, arthrinins A-C and arthrinins D were isolated from the sponge-derived Arthrinium sp. [48]. Additionally, (-)-hexylitaconic acid was isolated from sponge-derived Arthrinium sp. [49]. Three new chemical compounds, i.e., myrocin D, libertellenone $\mathrm{E}$, and libertellenone $\mathrm{F}$, were isolated from the marine fungus A. sacchari [50]. Plant-derived Arthrinium phaeospermum produced the antifungal compound arthrinic acid [51]. Biotic pesticide antifungal compounds can be useful in the control of infections caused by phytopathogenic fungi. The results of this study demonstrate the possibility of biological control of marine-derived fungal extracts.

\subsubsection{Antioxidant Activity}

In this study, 50 marine-derived fungal extracts were screened for their antioxidant capacity. The antioxidant activity was measured by the 2,2'-azinobis-(3-ethylbenzothiazoline-6-sulfonic acid) (ABTS) and 2,2-diphenyl-1-picrylhydrazyl (DPPH) radical scavenging activity. Among the fungal extracts, Arthrinium saccharicola KUC21221 and Aspergillus niger KUC21224 showed strong ABTS radical scavenging. A. saccharicola KUC21220 exhibited the highest DPPH radical scavenging activity, although A. niger KUC21224, Arthrinium sp. 2 KUC21220 and Xylariales sp. KUC21219 also exhibited activities. To the best of our knowledge, this is the first report of $A$. saccharicola activity on radical scavenging. Additionally, Diaporthe arecae, which is generally considered a plant pathogenic fungus, exhibited an antioxidant effect. Numerous marine filamentous fungi can produce antioxidant compounds and play an important role in the capture of free radicals. Excess free radicals or reactive oxygen species are harmful to human life [52]. Other studies have shown that various marine-derived fungal extracts are potent radical scavengers [53,54]. These efficient antioxidant compounds can be applied to the cosmetic industry. Kojic acid, a tyrosinase inhibitor, was screened through 600 marine-derived fungi and has been used as a cosmetic agent [21]. As an additional experiment, the radical scavenging activities of the extracts of cellulase-inducing media were investigated. However, there were no positive results among the extracts, although many fungal strains, such as A. saccharicola, showed high radical scavenging activity when cultivated on PDA (Table 1). It is believed that fungi are poor producers of antioxidants in cellulase-inducing media. This 
influence of culture media, such as the carbon source, on the secretion of secondary metabolites by fungi has been previously identified $[55,56]$.

\subsubsection{Cellulolytic Enzymes}

To investigate the specific cellulolytic enzyme activities of the isolated fungi, the filter paper unit (FPU), endoglucanase (EG), $\beta$-glucosidase (BGL) and $\beta$-xylosidase (BXL) activities of all fungal strains were measured. FPU indicates the total cellulolytic enzyme activity. EG creates a free chain-end by attacking the non-crystalline regions of the cellulose fiber. BGL acts on $\beta-1,4$ bonds linking two glucose or glucose-substituted molecules, and BXL catalyzes the hydrolysis of 1,4- $\beta$-D-xylans [57]. Among the fungal isolates, Arthrinium saccharicola KUC21221 showed the highest activities in FPU $(0.39 \mathrm{U} / \mathrm{mL}), \mathrm{EG}(0.38 \mathrm{U} / \mathrm{mL})$, and BGL $(1.04 \mathrm{U} / \mathrm{mL})$, and it showed a remarkable radical scavenging activity in this study (Table 1). These activities were comparable to the reported values of other wooddecaying fungi (Table 2). The FPU activity of A. saccharicola KUC21221 was also higher than that of Penicillium echinulatum $(0.27 \mathrm{U} / \mathrm{mL})$ [58]. It was expected that A. saccharicola KUC21221 would have a great saccharification ability because the FPU is closely related to the saccharification yield. According to a previous study, Hypoxylon oceanicum showed the highest EG activity among the five fungi isolated from mangroves [59]. However, A. saccharicola KUC21221 showed much higher activity in EG than did $H$. oceanicum $(0.04 \mathrm{U} / \mathrm{mL})$, and it exhibited higher BGL activity than did Aspergillus niger (1.02 U/mL) [60]. High BGL activity is important because BGL minimizes product inhibition and transglycosylation and promotes the production of cellulase inducer compounds [61]. Considering that A. saccharicola KUC21221 was derived from the marine environment, it was expected that it may secrete more enzyme when cultured in media with a proper amount of salinity [62]. Conversely, no strain showed a highly elevated BXL activity. Because all of the fungal strains were isolated from brown algae, low BXL activities could occur because the hemicellulose content is low in brown algae [63]. Our results support these fungal characteristics and further demonstrate the untapped potential of novel fungal lineages and their potentially useful metabolites in marine systems.

Table 2. Quantitative comparison of enzyme activities of Arthrinium saccharicola KUC21221 with other terrestrial fungi. ${ }^{a}$ FPU, filter paper unit; ${ }^{b}$ EG, endoglucanase; ${ }^{\mathrm{c}}$ BGL, $\beta$-glucosidase.

\begin{tabular}{|c|c|c|c|c|c|}
\hline Enzyme & Strains & Substrate & Cultivation Conditions & $\begin{array}{l}\text { Activity } \\
\text { (U/mL) }\end{array}$ & References \\
\hline \multirow[t]{2}{*}{$\mathrm{FPU}^{\mathrm{a}}$} & A. saccharicola KUC 21221 & Cellulose & Shake flask, $25^{\circ} \mathrm{C}, 168 \mathrm{~h}$ & 0.39 & This study \\
\hline & Penicillium echinulatum & Cellulose & Stir fermenter, $37^{\circ} \mathrm{C}, 192 \mathrm{~h}$ & 0.27 & {$[56]$} \\
\hline \multirow[t]{2}{*}{$\mathrm{EG}^{\mathrm{b}}$} & A. saccharicola KUC 21221 & Cellulose & Shake flask, $25^{\circ} \mathrm{C}, 168 \mathrm{~h}$ & 0.39 & This study \\
\hline & Hypoxylon oceanicum & $\begin{array}{l}\text { Cellulose }+ \\
\text { Filter paper }\end{array}$ & Shake flask, $25^{\circ} \mathrm{C}, 360 \mathrm{~h}$ & 0.04 & {$[57]$} \\
\hline \multirow[t]{2}{*}{$\mathrm{BGL}^{\mathrm{c}}$} & A. saccharicola KUC 21221 & Cellulose & Shake flask, $25^{\circ} \mathrm{C}, 168 \mathrm{~h}$ & 1.04 & This study \\
\hline & Aspergillus niger & Cellulose & Shake flask, $28^{\circ} \mathrm{C}, 168 \mathrm{~h}$ & 1.02 & {$[58]$} \\
\hline
\end{tabular}




\section{Experimental Section}

\subsection{Sampling and Isolation of Fungi}

Marine brown algae, Sargassum sp., were collected from Hyeopjae beach in Jeju, Korea. The samples were washed thoroughly with distilled water two times and cut into approximately $0.5 \mathrm{~cm} \times 0.5 \mathrm{~cm}$ squares using a sterile surgical blade. Small segments were treated with $70 \%$ ethanol for $60 \mathrm{~s}$ and then washed in sterile distilled water for $10 \mathrm{~s}[5,64]$. The segments were placed on malt extract agar (MEA) with $0.01 \%$ streptomycin and ampicillin to prevent bacterial growth. The grown fungi from the segments were transferred to MEA periodically and incubated at $25^{\circ} \mathrm{C}$.

\subsection{DNA Extraction, PCR and Identification}

Genomic DNA was extracted from fungal cultures using the AccuPrep Genomic DNA Extraction Kit (Bioneer, Seoul, Korea) according to the manufacturer's protocol. PCR reactions were carried out using the AccuPower PCR Premix Kit (Bioneer, Seoul, Korea) with the primers for the internal transcribed spacer (ITS) being ITS1F (5'-CTT GGT CAT TTA GAG GAA GTA A-3') [65] and ITS4 (5'-TCC TCC GCT TAT TGA TAT GC-3') [8], for nuclear large subunit rDNA (LSU) LR0R (5'-ACC CGC TGA ACT TAA GC-3')/LR5 (5'-TCC TGA GGG AAA CTT CG-3') or LR0R/LR7 (5'-TAC TAC CAC CAA GAT CT-3') [66], and for $\beta$-tubulin T10 (5'-ACG ATA GGT TCA CCT CCA GAC-3') /T2 (5'-TAG TGA CCC TTG GCC CAG TTG-3') [67] or Bt2a (5'-GGT AAC CAA ATC GGT GCT GCT TTC-3')/Bt2b (5'-ACC CTC AGT GTA GTG ACC CTT GGC-3') [68]. PCR amplification conditions for ITS and LSU were under the following temperature cycling parameters: $95{ }^{\circ} \mathrm{C}$ for $4 \mathrm{~min}$, followed by 30 cycles of $95{ }^{\circ} \mathrm{C}$ for $30 \mathrm{~s}, 55{ }^{\circ} \mathrm{C}$ for $30 \mathrm{~s}$, and $72{ }^{\circ} \mathrm{C}$ for $30 \mathrm{~s}$. An elongation step of $72{ }^{\circ} \mathrm{C}$ for $5 \mathrm{~min}$ was performed at the end. For $\beta$-tubulin, the conditions were as follows: $95^{\circ} \mathrm{C}$ for $5 \mathrm{~min}$, followed by 30 cycles of $95{ }^{\circ} \mathrm{C}$ for $35 \mathrm{~s}, 55^{\circ} \mathrm{C}$ for $50 \mathrm{~s}$, and $72{ }^{\circ} \mathrm{C}$ for $2 \mathrm{~min}$; an elongation step was performed at $72{ }^{\circ} \mathrm{C}$ for $7 \mathrm{~min}$. DNA sequencing was performed using Sanger method with 3730x1 DNA Analyzer (Life technology, Carlsbad, CA, USA) by Macrogen (Seoul, Korea). The sequences obtained in this study were deposited and the GenBank accession numbers are in Figure 2. The obtained DNA sequences were proofread, and a BLAST search was performed (http://blast.ncbi.nlm.nih.gov/Blast.cgi).

\subsection{Phylogenetic Analysis}

The obtained sequences were aligned using MAFFT 7.130 [69] and modified manually using MacClade 4.08 [70]. The ITS, LSU and $\beta$-tubulin datasets contained 50 taxa and 778, 1005 and 657 nucleotide characters, respectively. They were respectively tested by MrModeltest 2.3 with default options using the AIC criteria [71]. The GTR $+\mathrm{I}+\mathrm{G}$ model was chosen under the AIC criteria for all datasets. Three datasets were combined and the selected model was applied. Bayesian analysis was performed using MrBayes 3.2.1 [72]. Two runs with 1,000,000 generations were performed, and every 100 th generation was sampled. Among them, the first $25 \%$ of the trees was eliminated, and the last $75 \%$ was used. A 50\% majority-rule consensus tree was constructed, and tree reliability was confirmed by posterior probability. 
The phylogenetic tree based on ITS was constructed to prove the identity of each fungus. The ITS sequences were aligned using MAFFT 7.130 with reference sequences obtained from GenBank using a BLAST search. The dataset has 95 taxa and 810 nucleotide characters. Phylogenetic analysis was performed using the described method. The GTR $+\mathrm{I}+\mathrm{G}$ model was selected under the AIC criteria.

To confirm the identification of Arthrinium spp., which shows strong bioactivity, an additional phylogenetic tree was constructed with reference sequences from Crous and Groenewald [11]. Phylogenetic analysis was performed as described in this study. The ITS, LSU and $\beta$-tubulin datasets contained 38 taxa and 643, 893 and 560 nucleotide characters, respectively. The $\mathrm{SYM}+\mathrm{I}+\mathrm{G}$ model was selected for the ITS dataset, and the GTR $+\mathrm{I}+\mathrm{G}$ model was chosen for the last two datasets.

\subsection{Biological Activity}

\subsubsection{Preparation of Extracts}

A total of 50 fungal species were cultivated on $50 \mathrm{~mL}$ of potato dextrose agar (PDA; Difco, Detroit, MI, USA) at $25^{\circ} \mathrm{C}$ for 7 days in the dark. After the incubation periods, the solid culture was extracted with $200 \mathrm{~mL}$ of methanol (SK chemicals, Ulsan, Korea) for a day. The harvested MeOH solution was filtered through Whatman No. 1 filter paper. The solvents were evaporated to dryness under a vacuum at $37{ }^{\circ} \mathrm{C}$, and $4{ }^{\circ} \mathrm{C}$ was used during the cooling circulation to obtain effective yields. The condensed residues were re-dissolved in ethyl acetate and distilled water $(1: 1)$. Then, the partitioned ethyl acetate fraction was evaporated. The extracts were solubilized in dimethyl sulfoxide (DMSO; Junsei, Tokyo, Japan) to a final concentration of $10 \mathrm{mg} / \mathrm{mL}$ and stored at $4{ }^{\circ} \mathrm{C}$ before testing [2].

\subsubsection{Antifungal Activity}

The capability of marine-derived fungi to control three plant pathogenic fungi was evaluated. Fusarium oxysporum KUC20267, Botrytis cinerea KUC21265, and Collectotrichum gloeosporioides KUC21266 were tested as the target fungi. Each well of a 96-well microplate contained $2 \mu \mathrm{L}$ of fungal extracts, $20 \mu \mathrm{L}$ of spore suspension, and $178 \mu \mathrm{L}$ of media [73]. The plant pathogenic fungi spore suspension was adjusted to $4 \times 10^{6}$ per mL. The absorbance was measured every $24 \mathrm{~h}$ at $595 \mathrm{~nm}$.

\subsubsection{Antioxidant Activity}

\section{ABTS Radical-Scavenging Assay}

The 2,2'-azinobis-(3-ethylbenzothiazoline-6-sulfonic acid) (ABTS) (Sigma-Aldrich Inc., St. Louis, MO, USA) radical-scavenging activity was measured as described by Roberta et al. (1999) [47]. ABTS was dissolved in phosphate-buffered saline (PBS, $\mathrm{pH} 7.4$ ) to $7 \mathrm{mM}$, and the ABTS radical cation was produced by adding potassium persulfate at a final concentration of $2.45 \mathrm{mM}$. The mixture was incubated for $24 \mathrm{~h}$ at RT in the dark, and the resultant ABTS radical solution was diluted to an absorbance of $0.70( \pm 0.02)$ at $734 \mathrm{~nm}$. A $990 \mu \mathrm{L}$ aliquot of the prepared ABTS radical solution was reacted with $10 \mu \mathrm{L}$ of the extracts $(10 \mathrm{mg} / \mathrm{mL})$ in a cuvette. After $6 \mathrm{~min}$, the absorbance at $734 \mathrm{~nm}$ was measured using a spectrophotometer. Trolox was used as the antioxidant positive control solution. 


\section{DPPH Radical-Scavenging Assay}

The 2,2-diphenyl-1-picrylhydrazyl (DPPH) (Sigma-Aldrich Inc., St. Louis, MO, USA) radical scavenging activity of the samples was analyzed according to Fukumoto et al. [4]. The DPPH solution was prepared in methanol $(80 \%)$ at $150 \mu \mathrm{M}$. For analysis in the 96 -well plate, we added $22 \mu \mathrm{L}$ of the extracts of the sample $(10 \mathrm{mg} / \mathrm{mL})$ and $200 \mu \mathrm{L}$ of the DPPH solution to each well and then incubated the plate at room temperature for $30 \mathrm{~min}$. The absorbance at $520 \mathrm{~nm}$ was measured using a microplate reader. A control consisted of $22 \mu \mathrm{L}$ of methanol instead of the sample extracts. Trolox was used as the antioxidant standard.

\subsubsection{Cellulolytic Enzyme}

Enzyme Preparation

All fungal isolates were inoculated on solid medium containing 2\% (w/v) malt extract (Bacto, Sparks, MD, USA) and 1.5\% agar powder (Showa, Tokyo, Japan). The strains were grown for seven days, and two agar plugs of each strain were used for the inoculums. To prepare the fungal enzyme, the fungi were cultivated in $50 \mathrm{~mL}$ conical tubes that contained $10 \mathrm{~mL}$ Mandels' medium ( $0.3 \mathrm{~g}$ of urea, $1.4 \mathrm{~g}$ of $\mathrm{KH}_{2} \mathrm{PO}_{4}, 2.0 \mathrm{~g}$ of $\left(\mathrm{NH}_{4}\right)_{2} \mathrm{SO}_{4}, 0.3 \mathrm{~g}$ of $\mathrm{CaCl}_{2}, 0.3 \mathrm{~g}$ of $\mathrm{MgSO}_{4}, 0.25 \mathrm{~g}$ of yeast extract, $0.75 \mathrm{~g}$ of peptone, $5 \mathrm{mg}$ of $\mathrm{FeSO}_{4} \cdot 7 \mathrm{H}_{2} \mathrm{O}, 36 \mathrm{mg}$ of $\mathrm{COCl}_{2} \cdot 6 \mathrm{H}_{2} \mathrm{O}, 1.8 \mathrm{mg}$ of $\mathrm{MnSO}_{4} \cdot \mathrm{H}_{2} \mathrm{O}$, and $2.5 \mathrm{mg}$ of $\mathrm{ZnSO}_{4} \cdot 7 \mathrm{H}_{2} \mathrm{O}$ per liter of distilled water) with $1 \%$ cellulose as the sole carbon source [74]. Fungal cultures were incubated aerobically for 1 week at $25^{\circ} \mathrm{C}$ on a rotary shaker at $150 \mathrm{rpm}$ in the dark. The cultures were prepared in triplicate, and the mean values are presented. After cultivation, the samples were centrifuged at $4000 \mathrm{rpm}$ for $25 \mathrm{~min}$ at $4{ }^{\circ} \mathrm{C}$, and the supernatant was extracted and filtered through a $0.45 \mu \mathrm{m}$ filter (Minisart, Sartorius, Göttingen, Germany) to determine the enzymatic activities of the crude enzyme solutions.

\section{Enzyme Assays}

The FPU activities were measured using a $60 \mu \mathrm{L}$ filter paper assay (FPA) method [75]. Briefly, the reaction mixtures were prepared in a total volume of $60 \mu \mathrm{L}$ consisting of $20 \mu \mathrm{L}$ of the enzyme solutions and $40 \mu \mathrm{L}$ of $50 \mathrm{mM}$ citrate buffer ( $\mathrm{pH} 4.8$ ) in a $0.2 \mathrm{~mL}$ PCR tube (Axygen, cat. No. 321-10-051); the substrate was a $7 \mathrm{~mm}$ diameter Whatman No. 1 filter paper disk. After one hour of the reaction at $50{ }^{\circ} \mathrm{C}$, $120 \mu \mathrm{L}$ of dinitrosalicylic acid (DNS) was added. The tubes were boiled and cooled for 5 min each. Thirty-six microliters of the reaction mixtures were transferred to a 96-well tissue microplate (Falcon, cat. No. 353072) with $160 \mu \mathrm{L}$ of distilled water, and the absorbance was measured at $540 \mathrm{~nm}$. The absorbance was used to calculate the FPU using glucose as the standard. One FPU was defined as $1 \mathrm{mM}$ of glucose equivalent released per minute. The EG activities were assayed according to standard procedures [76,77]. The procedure was similar to the above FPA method. Briefly, the reaction mixtures were prepared in a total volume of $50 \mu \mathrm{L}$ consisting of $25 \mu \mathrm{L}$ of enzyme solutions and $25 \mu \mathrm{L}$ of $2 \% \mathrm{CMC}$ in $50 \mathrm{mM}$ citrate buffer $(\mathrm{pH} 4.8)$ in a $0.2 \mathrm{~mL}$ PCR tube. After one hour of the reaction at $50{ }^{\circ} \mathrm{C}, 150 \mu \mathrm{L}$ of the DNS reagent was added. The following procedures were the same as the above FPA method. The tubes were boiled and cooled for $5 \mathrm{~min}$ each. Thirty-six microliters of the reaction 
mixtures was transferred to flat-bottom 96-well tissue culture plates with $160 \mu \mathrm{L}$ of distilled water, and the absorbance was measured at $540 \mathrm{~nm}$. The absorbance was used to calculate the EG activity using glucose as the standard. One unit of EG activity was defined as $1 \mathrm{mM}$ of glucose equivalent released per minute. The activities of BGL and BXL were determined according to the method of Valásková and Baldrian [78]. These activities were determined by measuring the concentration of $p$-nitrophenyl (pNP) released by $p$-nitrophenyl glucosidase ( $\mathrm{pNPG}$ ) or $p$-nitrophenyl xylosidase (pNPX). Briefly, reaction mixtures consisting of $20 \mu \mathrm{L}$ of the enzyme solutions, $20 \mu \mathrm{L}$ of $10 \mathrm{mM}$ pNPG or pNPX, and $20 \mu \mathrm{L}$ of $1 \mathrm{M}$ sodium acetate buffer ( $\mathrm{pH} 5.0$ ) were incubated for 5 and $10 \mathrm{~min}$, respectively, at $50{ }^{\circ} \mathrm{C}$. The reaction was stopped by adding $20 \mu \mathrm{L}$ of $2 \mathrm{M} \mathrm{Na}_{2} \mathrm{CO}_{3}$, and the absorbance was measured at $405 \mathrm{~nm}$. One unit of BGL or BXL activity was defined as the amount of enzyme that released $1 \mathrm{mM}$ of pNP per minute [79].

\subsection{Statistical Analysis}

Inhibitory concentration ( $\mathrm{IC}_{50}$ ) values were calculated from nonlinear regression analysis using the SAS software (version 9.2 by SAS Institute Inc., Cary, NC, USA).

\section{Conclusions}

In conclusion, this study provided reliable DNA information for marine-derived fungi and their biological activities. A total of 50 fungal strains were obtained from the brown algae Sargassum sp. Based on the BLAST search with ITS, LSU, and the $\beta$-tubulin region, a phylogenetic analysis was performed to verify the identification. Among the collected fungi, Corollospora angusta was the dominant species, and the most diverse genus was Arthrinium. In addition, Arthrinium spp. showed relatively strong biological activities for antifungal, antioxidant, and cellulolytic activity. The potential bioactive compounds will be isolated and purified in the near future.

\section{Acknowledgments}

This research was supported by Basic Science Research Program through the National Research Foundation of Korea (NRF) funded by the Ministry of Education (NRF-2013R1A1A2A10011390) and by NRF (National Research Foundation of Korea) Grant funded by the Korean Government (NRF-2012-Fostering Core Leaders of the Future Basic Science Program, NRF-2012H1A8003235).

\section{Author Contributions}

Joo-Hyun Hong and Jae-Jin Kim conceived and designed the experiments; Joo-Hyun Hong, Seokyoon Jang, Young Mok Heo, and Mihee Min performed the experiments; all the authors analyzed the data; Joo-Hyun Hong, Seokyoon Jang and Young Mok Heo wrote and revised the manuscript.

\section{Conflicts of Interest}

The authors declare no conflict of interest. 


\section{References}

1. Abdel-Wahab, M.A.; Pang, K.L.; Nagahama, T.; Abdel-Aziz, F.A.; Jones, E.G. Phylogenetic evaluation of anamorphic species of Cirrenalia and Cumulospora with the description of eight new genera and four new species. Mycol. Prog. 2010, 9, 537-558.

2. Manimegalai, K.; Devi, N.A.; Padmavathy, S. Marine fungi as a source of secondary metabolites of antibiotics. Int. J. Biotechnol. Bioeng. Res. 2013, 4, 275-282.

3. Park, M.S.; Fong, J.J.; Oh, S.Y.; Kwon, K.K.; Sohn, J.H.; Lim, Y.W. Marine-derived Penicillium in Korea: Diversity, enzyme activity, and antifungal properties. Antonie Leeuwenhoek 2014, 106, 331-345.

4. Jones, E.B. Are there more marine fungi to be described? Bot. Mar. 2011, 54, 343-354.

5. Suryanarayanan, T.S.; Venkatachalam, A.; Thirunavukkarasu, N.; Ravishankar, J.P.; Doble, M.; Geetha, V. Internal mycobiota of marine macroalgae from the Tamilnadu coast: Distribution, diversity and biotechnological potential. Bot. Mar. 2010, 53, 457-468.

6. Zuccaro, A.; Schoch, C.L.; Spatafora, J.W.; Kohlmeyer, J.; Draeger, S.; Mitchell, J.I. Detection and identification of fungi intimately associated with the brown seaweed Fucus serratus. Appl. Environ. Microbiol. 2008, 74, 931-941.

7. Suryanarayanan, T.S. Fungal endosymbionts of seaweeds. In Biology of Marine Fungi; Springer: Berlin, Germany, 2012.

8. White, T.J.; Bruns, T.D.; Lee. S.; Taylor, J.W. Amplification and direct sequencing of fungal ribosomal RNA genes for phylogenetics. In PCR Protocols: A Guide to Methods and Applications; Academic Press: New York, NY, USA, 1990; pp. 315-322.

9. Schoch, C.L.; Seifert, K.A.; Huhndorf, S.; Robert, V.; Spouge, J.L.; Levesque, C.A.; Griffith, G.W. Nuclear ribosomal internal transcribed spacer (ITS) region as a universal DNA barcode marker for Fungi. Proc. Natl. Acad. Sci. USA 2012, 109, 6241-6246.

10. Huh, N.; Jang, Y.; Lee, J.; Kim, G.-H.; Kim, J.-J. Phylogenetic analysis of major molds inhabiting woods and their discoloration characteristics. Part 1. Genus Trichoderma. Holzforschung 2011, 65, 257-263.

11. Crous, P.W.; Groenewald, J.Z. A phylogenetic re-evaluation of Arthrinium. IMA Fungus 2013, 4, $133-154$.

12. James, T.Y.; Kauff, F.; Schoch, C.L.; Matheny, P.B.; Hofstetter, V.; Cox, C.J.; Celio, G.; Gueidan, C.; Fraker, E.; Miadlikowska, J.; et al. Reconstructing the early evolution of Fungi using a six-gene phylogeny. Nature 2006, 443, 818-822.

13. Sakayaroj, J.; Pang, K.L.; Jones, E.G. Multi-gene phylogeny of the Halosphaeriaceae: Its ordinal status, relationships between genera and morphological character evolution. Fungal Divers. 2011, 46, 87-109.

14. Mayer, A.M.; Rodríguez, A.D.; Berlinck, R.G.; Fusetani, N. Marine pharmacology in 2007-2008: Marine compounds with antibacterial, anticoagulant, antifungal, anti-inflammatory, antimalarial, antiprotozoal, antituberculosis, and antiviral activities; affecting the immune and nervous system, and other miscellaneous mechanisms of action. Comp. Biochem. Physiol. C Toxicol. Pharmacol. 2011, 153, 191-222. 
15. Kelecom, A. Secondary metabolites from marine microorganisms. An. Acad. Bras. Cienc. 2002, 74, 151-170.

16. Bugni, T.S.; Ireland, C.M. Marine-derived fungi: A chemically and biologically diverse group of microorganisms. Nat. Prod. Rep. 2004, 21, 143-163.

17. Wei, M.Y.; Wang, C.Y.; Liu, Q.A.; Shao, C.L.; She, Z.G.; Lin, Y.C. Five sesquiterpenoids from a marine-derived fungus Aspergillus sp. isolated from a gorgonian Dichotella gemmacea. Mar. Drugs 2010, 8, 941-949.

18. Bai, Z.Q.; Lin, X.; Wang, J.; Zhou, X.; Liu, J.; Yang, B.; Yang, X.; Liao, S.; Wang, L.; Liu, Y. New Meroterpenoids from the Endophytic Fungus Aspergillus flavipes AIL8 Derived from the Mangrove Plant Acanthus ilicifolius. Mar. Drugs 2015, 13, 237-248.

19. Kito, K.; Ookura, R.; Yoshida, S.; Namikoshi, M.; Ooi, T.; Kusumi, T. New cytotoxic 14-membered macrolides from marine-derived fungus Aspergillus ostianus. Org. Lett. 2008, 10, 225-228.

20. Fenical, W.; Jensen, P.R.; Cheng, X.C. Avraincillamide, a Cytotoxic Marine Natural Product, and Derivatives Thereof. U.S. Patent 6,066,635, 23 May 2000.

21. Balboa, E.M.; Conde, E.; Soto, M.L.; Pérez-Armada, L.; Domínguez, H. Cosmetics from Marine Sources. In Hb25_Springer Handbook of Marine Biotechnology; Springer: Berlin, Germany, 2015; pp. 1015-1042.

22. Veiga, M.; Esparis, A.; Fabregas, J. Isolation of cellulolytic actinomycetes from marine sediments. Appl. Environ. Microbiol. 1983, 46, 286.

23. Cowie, G.L.; Hedges, J.I. Carbohydrate sources in a coastal marine environment. Geochim. Cosmochim. Acta 1984, 48, 2075-2087.

24. Rohrmann, S.; Molitoris, H.P. Screening for wood-degrading enzymes in marine fungi. Can. J. Bot. 1992, 70, 2116-2123.

25. Meyers, S.P.; Prindle, B.; Reynolds, E.S. Cellulolytic activity of marine fungi. Degradation of lignocellulose material. Tappi 1960, 43, 534-538.

26. Nakagiri, A.; Tokura, R. Taxonomic studies of the genus Corollospora (Halosphaeriaceae, Ascomycotina) with descriptions of seven new species. Trans. Mycol. Soc. Jpn. 1987, 28, 413-436.

27. Prasannarai, K.; Sridhar, K.R. Abundance and diversity of marine fungi on intertidal woody litter of the west coast of India on prolonged incubation. Fungal Divers. 2003, 14, 127-141.

28. Luo, W.; Vrijmoed, L.L.; Jones, E.B. Screening of marine fungi for lignocellulose-degrading enzyme activities. Bot. Mar. 2005, 48, 379-386.

29. Khan, S.A.; Hamayun, M.; Kim, H.-Y.; Yoon, H.-J.; Seo, J.-C.; Choo, Y.-S.; Lee, I.-J.; Kim, S.D.; Rhee, I.-K.; Kim J.-G. A new strain of Arthrinium phaeospermum isolated from Carex kobomugi Ohwi is capable of gibberellin production. Biotechnol. Lett. 2009, 31, 283-287.

30. Kim, J.-J.; Lee, S.-S.; Ra, J.-B.; Lee, H.; Huh, N.; Kim, G.-H. Fungi associated with bamboo and their decay capabilities. Holzforschung 2011, 65, 271-275.

31. Martínez-Cano, C.; Grey, W.E.; Sands, D.C. First report of Arthrinium arundinis causing kernel blight on barley. Plant Dis. 1992, 76, 1077, doi:10.1094/PD-76-1077B.

32. Saccardo, P.A. Sylloge Fungorum; Sumptibus Auctoris: Pavia, Italy, 1931; Volume 25, p. 771.

33. Miao, L.I.; Kwong, T.F.; Qian, P.Y. Effect of culture conditions on mycelial growth, antibacterial activity, and metabolite profiles of the marine-derived fungus Arthrinium cf saccharicola. Appl. Microbiol. Biotechnol. 2006, 72, 1063-1073. 
34. Glenn, A.E.; Bacon, C.W.; Price, R.; Hanlin, R.T. Molecular phylogeny of Acremonium and its taxonomic implications. Mycologia 1996, 88, 369-383.

35. Samson, R.A.; Hoekstra, E.S.; Frisvad, J.C. Introduction to Food-And Airborne Fungi, 7th ed.; Centraalbureau voor Schimmelcultures: Utrecht, The Netherlands, 2004.

36. Zuccaro, A.; Summerbell, R.C.; Gams, W.; Schroers, H.J.; Mitchell, J.I. A new Acremonium species associated with Fucus spp., and its affinity with a phylogenetically distinct marine Emericellopsis clade. Stud. Mycol. 2004, 50, 283-297.

37. Oren, A.; Gunde-Cimerman, N. Fungal Life in the Dead Sea. In Biology of Marine Fungi; Springer: Berlin, Germany, 2012.

38. Khambhaty, Y.; Mody, K.; Basha, S.; Jha, B. Kinetics, equilibrium and thermodynamic studies on biosorption of hexavalent chromium by dead fungal biomass of marine Aspergillus niger. Chem. Eng. J. 2009, 145, 489-495.

39. Xue, D.S.; Chen, H.Y.; Ren, Y.R.; Yao, S.J. Enhancing the activity and thermostability of thermostable $\beta$-glucosidase from a marine Aspergillus niger at high salinity. Process Biochem. 2012, 47, 606-611.

40. Gordon, T.R.; Martyn, R.D. The evolutionary biology of Fusarium oxysporum. Annu. Rev. Phytopathol. 1997, 35, 111-128.

41. Zhang, Y.; Mu, J.; Feng, Y.; Kang, Y.; Zhang, J.; Gu, P.J.; Wang, Y.; Ma, L.-F.; Zhu, Y.H. Broad-spectrum antimicrobial epiphytic and endophytic fungi from marine organisms: Isolation, bioassay and taxonomy. Mar. Drugs 2009, 7, 97-112.

42. Khallil, A.R.; El-Hissy, F.T.; Bagy, M.M.K. Mycoflora of mangroves of Red Sea in Egypt. Folia Microbiol. 1991, 36, 456-464.

43. Hong, S.B.; Kim, D.H.; Lee, M.; Baek, S.Y.; Kwon, S.W.; Houbraken, J.; Samson, R.A. Zygomycota associated with traditional meju, a fermented soybean starting material for soy sauce and soybean paste. J. Microbiol. 2012, 50, 386-393.

44. Yang, S.; Lee, J.; Kwak, J.; Kim, K.; Seo, M.; Lee, Y.W. Fungi associated with the traditional starter cultures used for rice wine in Korea. J. Kor. Soc. Appl. Biol. Chem. 2011, 54, 933-943.

45. Vicente, G.; Bautista, L.F.; Rodríguez, R.; Gutiérrez, F.J.; Sádaba, I.; Ruiz-Vázquez, R.M.; Torres-Martínezb, S.; Garre, V. Biodiesel production from biomass of an oleaginous fungus. Biochem. Eng. J. 2009, 48, 22-27.

46. Lübbehüsen, T.L.; Nielsen, J.; Mcintyre, M. Aerobic and anaerobic ethanol production by Mucor circinelloides during submerged growth. Appl. Microbiol. Biotechnol. 2004, 63, 543-548.

47. Jiménez, E.; Dorta, F.; Medina, C.; Ramírez, A.; Ramírez, I.; Peña-Cortés, H. Anti-phytopathogenic activities of macro-algae extracts. Mar. Drugs 2011, 9, 739-756.

48. Ebada, S.S.; Schulz, B.; Wray, V.; Totzke, F.; Kubbutat, M.H.; Müller, W.E.; Hamacherf, A.; Kassackf, M.U.; Ling, W.; Proksch, P. Arthrinins A-D: Novel diterpenoids and further constituents from the sponge derived fungus Arthrinium sp. Bioorg. Med. Chem. 2011, 19, 4644-4651.

49. Tsukamoto, S.; Yoshida, T.; Hosono, H.; Ohta, T.; Yokosawa, H. Hexylitaconic acid: A new inhibitor of p53-HDM2 interaction isolated from a marine-derived fungus, Arthrinium sp. Bioorg. Med. Chem. Lett. 2006, 16, 69-71. 
50. Tsukada, M.; Fukai, M.; Miki, K.; Shiraishi, T.; Suzuki, T.; Nishio, K.; Sugita, T.; Ishino, M.; Kinoshita, K.; Takahashi, K.; et al. Chemical constituents of a marine fungus, Arthrinium sacchari. J. Nat. Prod. 2011, 74, 1645-1649.

51. Bloor, S. Arthrinic acid, a novel antifungal polyhydroxyacid from Arthrinium phaeospermum. J. Antibiot. 2008, 61, 515-517.

52. Amens, B.N. Dietary carcinogens and anticarcinogens. Science 1983, 221, 1256.

53. Li, X.; Li, X.M.; Xu, G.M.; Li, C.S.; Wang, B.G. Antioxidant metabolites from marine alga-derived fungus Aspergillus wentii EN-48. Phytochem. Lett. 2014, 7, 120-123.

54. Sun, H.H.; Mao, W.J.; Chen, Y.; Guo, S.D.; Li, H.Y.; Qi, X.H.; Chen, Y.L.; Xu, J. Isolation, chemical characteristics and antioxidant properties of the polysaccharides from marine fungus Penicillium sp. F23-2. Carbohydr. Polym. 2009, 78, 117-124.

55. Parra, R.; Aldred, D.; Magan, N. Medium optimization for the production of the secondary metabolite squalestatin S1 by a Phoma sp. combining orthogonal design and response surface methodology. Enzym. Microb. Technol. 2005, 37, 704-711.

56. Gogoi, D.K.; Boruah, H.P.D.; Saikia, R.; Bora, T.C. Optimization of process parameters for improved production of bioactive metabolite by a novel endophytic fungus Fusarium sp. DF2 isolated from Taxus wallichiana of North East India. World J. Microbiol. Biotechnol. 2008, 24, 79-87.

57. Sun, Y.; Cheng, J. Hydrolysis of lignocellulosic materials for ethanol production: A review. Bioresour. Technol. 2002, 83, 1-11.

58. Martins, L.F.; Kolling, D.; Camassola, M.; Dillon, A.J.P.; Ramos, L.P. Comparison of Penicillium echinulatum and Trichoderma reesei cellulases in relation to their activity against various cellulosic substrates. Bioresour. Technol. 2008, 99, 1417-1424.

59. Pointing, S.B.; Buswell, J.A.; Jones, E.G.; Vrijmoed, L.L.P. Extracellular cellulolytic enzyme profiles of five lignicolous mangrove fungi. Mycol. Res. 1999, 103, 696-700.

60. Narasimha, G.; Sridevi, A.; Buddolla, V.; Subhosh, C.M.; Rajasekhar, R.B. Nutrient effects on production of cellulolytic enzymes by Aspergillus niger. Afr. J. Biotechnol. 2006, 5, 472-476.

61. Gao, L.; Gao, F.; Jiang, X.; Zhang, C.; Zhang, D.; Wang, L.; Wu, G.; Chen, S. Biochemical characterization of a new $\beta$-glucosidase (Cel3E) from Penicillium piceum and its application in boosting lignocelluloses bioconversion and forming disaccharide inducers: New insights into the role of $\beta$-glucosidase. Process Biochem. 2014, 49, 768-774.

62. Jones, E.G.; Jennings, D.H. The effect of salinity on the growth of marine fungi in comparison with non-marine species. Trans. Br. Mycol. Soc. 1964, 47, 619-625.

63. Borines, M.G.; de Leon, R.L.; McHenry, M.P. Bioethanol production from farming non-food macroalgae in Pacific island nations: Chemical constituents, bioethanol yields, and prospective species in the Philippines. Renew. Sustain. Energy Rev. 2011, 15, 4432-4435.

64. Kjer, J.; Debbab, A.; Aly, A.H.; Prokasc, P. Methods for isolation of marine-deried endophytic fungi and their bioactive secondary products. Nat. Protoc. 2010, 5, 479-490.

65. Gardes, M.; Bruns, T.D. ITS primers with enhanced specificity for basidiomycetes: Application to the identification of mycorrhizae and rusts. Mol. Ecol. 1993, 2, 113-118.

66. Vilgalys, R.; Hester, M. Rapid genetic identification and mapping of enzymatically amplified ribosomal DNA from several Cryptococcus species. J. Bacteriol. 1990, 172, 4238-4246. 
67. O’Donnell, K.; Cigelnik, E. Two divergent intragenomic rDNA ITS2 types within a monophyletic lineage of the fungus Fusarium are nonorthologous. Mol. Phylogenet. Evol. 1997, 7, 103-116.

68. Glass, N.; Donaldson, G. Development of primer sets designed for use with the PCR to amplify conserved genes from filamentous ascomycetes. Appl. Environ. Microbiol. 1995, 61, 1323-1330.

69. Katoh, K.; Standley, D.M. MAFFT Multiple Sequence Alignment Software Version 7: Improvements in Performance and Usability. Mol. Biol. Evol. 2013, 30, 772-780.

70. Maddison, W.P.; Maddison, D.R. MacClade 4: Analysis of Phylogeny and Character Evolution, Version 4.08; Sinauer Associates: Sunderland, MA, USA, 2005.

71. Nylander, J.A.A. MrModeltest v2. Program Distributed by the Author; Evolutionary Biology Centre, Uppsala University: Uppsala, Sweden, 2004.

72. Ronquist, F.; Huelsenbeck, J.P. MrBayes 3: Bayesian phylogenetic inference under mixed models. Bioinformatics 2003, 19, 1572-1574.

73. Hong, J.H.; Lee, J.; Min, M.; Ryu, S.M.; Lee, D.; Kim, G.-H.; Kim, J.-J. 6-Pentyl- $\alpha$-pyrone as an anti-sapstain compound produced by Trichoderma gamsii KUC1747 inhibits the germination of ophiostomatoid fungi. Holzforschung 2014, 68, 769-774.

74. Lee, Y.M.; Lee, H.; Kim, G.-H.; Kim, J.-J. Miniaturized enzyme production and development of micro-assays for cellulolytic and xylanolytic enzymes. J. Microbiol. Methods 2011, 86, 124-127.

75. Xiao, Z.; Storms, R.; Tsang, A. Microplate-based filter paper assay to measure total cellulase activity. Biotechnol. Bioeng. 2004, 88, 832-837.

76. Ghose, T.K. Measurement of cellulase activities. Pure Appl. Chem. 1987, 59, 257-268.

77. Bailey, M.J.; Biely, P.; Poutanen, K. Interlaboratory testing of methods for assay of xylanase activity. J. Biotechnol. 1992, 23, 257-270.

78. Valásková, V.; Baldrian, P. Degradation of cellulose and hemicelluloses by the brown rot fungus Piptoporus betulinus: Production of extracellular enzymes and characterization of the major cellulases. Microbiology 2006, 152, 3613-3622.

79. Lee, J.; Jang, Y.; Lee, H.; Lee, S.; Kim, G.-H.; Kim, J.-J. Screening for xylanase and $\beta$-xylosidase production from wood-inhabiting Penicillium strains for potential use in biotechnological applications. Holzforschung 2012, 66, 267-271.

(C) 2015 by the authors; licensee MDPI, Basel, Switzerland. This article is an open access article distributed under the terms and conditions of the Creative Commons Attribution license (http://creativecommons.org/licenses/by/4.0/). 